

\section{Daftar Isi (Table of Content) Journal of Government
Civil Society}

\begin{tabular}{|c|c|}
\hline \multirow{3}{*}{$146-163$} & $\begin{array}{l}\text { New Public Management (New Public Comparison Meta-Analysis } \\
\text { Developed and Developing Country Policies) }\end{array}$ \\
\hline & Dyah Mutiarin², Misran $^{1}$ \\
\hline & $\begin{array}{l}\text { ( }{ }^{1} \text { Department of Government Affairs and Administration, Universitas Muhammadiyah } \\
\text { Yogyakarta, Indonesia) } \\
\text { (' Jusuf Kalla School of Government, Universitas Muhammadiyah Yogyakarta, Indonesia) }\end{array}$ \\
\hline \multirow{3}{*}{$164-183$} & $\begin{array}{l}\text { Policy Networks: Actors, Interests, and Power Relations in the Jakarta } \\
\text { Reclamation Project }\end{array}$ \\
\hline & Rizki Hegia Sampurna1,2, Chih-Chieh Chou ${ }^{1}$ \\
\hline & $\begin{array}{l}\text { (' Department of Political Science, National Cheng Kung University (NCKU), Taiwan) } \\
\text { ( }{ }^{2} \text { Department of Public Administration, Universitas Muhammadiyah Sukabumi (UMMI), } \\
\text { Indonesia) }\end{array}$ \\
\hline \multirow{3}{*}{$184-197$} & $\begin{array}{l}\text { National Insights and Youth Political Attitudes in Rural Lampung Against } \\
\text { Negative Campaign }\end{array}$ \\
\hline & Hertanto $^{1}$, Handi Mulyaningsih², Asep Nurjaman ${ }^{3}$ \\
\hline & $\begin{array}{l}\left({ }^{1} \text { Departement of Government Science, Universitas Lampung, Indonesia) }\right. \\
\left({ }^{2} \text { Departement of Sociology, Universitas Lampung, Indonesia) }\right. \\
\left({ }^{3} \text { Departement of Government Science, Universitas Muhammadiyah Malang, Indonesia) }\right.\end{array}$ \\
\hline \multirow{3}{*}{$198-213$} & $\begin{array}{l}\text { Ethnic Identity and Local Politics: Study on Regional Head Election in } \\
\text { Merauke Regency } 2020\end{array}$ \\
\hline & Misran$^{1}$, Wahdania Sardi ${ }^{1}, Z^{2}$ uly Qodir ${ }^{1}$ \\
\hline & $\begin{array}{l}\left({ }^{1} \text { Department of Government Affairs and Administration, Jusuf Kalla School of Government, }\right. \\
\text { Universitas Muhammadiyah Yogyakarta, Indonesia) }\end{array}$ \\
\hline \multirow{3}{*}{$214-236$} & $\begin{array}{l}\text { Stakeholder Collaboration Model for Ecotourism Development: A Case } \\
\text { Study from Batu City, East Java Province }\end{array}$ \\
\hline & $\begin{array}{l}\text { I Gede Eko Putra Sri Sentanu' }{ }^{1} \text {, Ardian Prabowo', Klara Kumalasari'1, } \\
\text { Aulia Puspaning Galih', Rendra Eko Wismanu }{ }^{1}\end{array}$ \\
\hline & (' Departement of Public Administration, Universitas Brawijaya, Indonesia) \\
\hline
\end{tabular}


Farmers Social Movement Studies: A Systematic Literature Review for A Conceptual Model

$237-262 \quad$ Wahyudi $^{1}$

(' Department of Sociology, Universitas Muhammadiyah Malang, Indonesia)

Factors Affecting Trust in E-Government

Ulung Pribadi' ${ }^{1}$, Muhammad Iqbal ${ }^{2}$, Fittia Restiane ${ }^{3}$

263 - 276 (1 Post-Graduate Program Universitas Muhammadiyah Yogyakarta, Indonesia)

( ${ }^{2}$ Department of Political Science National Cheng Kung University, Taiwan)

$\left({ }^{3}\right.$ Department of Government Affairs and Administration Universitas Muhammadiyah Yogyakarta, Indonesia) 


\title{
Ethnic Identity and Local Politics: Study on Regional Head Election in Merauke Regency 2020
}

\author{
Misran $^{1 *}$, Wahdania Sardi ${ }^{1}$, Zuly Qodir $^{1}$ \\ $1^{1^{*}}$ Department of Government Affairs and Administration, Jusuf Kalla School of Government, Universitas \\ Muhammadiyah Yogyakarta, Indonesia \\ *E-mail Correspondence: misranalfarabi@gmail com.
}

\begin{abstract}
In the Regional Head Election of Merauke Regency, there was a contestation between tribes to win the candidate. In this contestation, there was a conflict between ethnic groups, namely the indigenous Papuans and migrants. This study aims to discuss the political struggle of the Merauke Regency to get political support through entities. This study uses an analytical approach to research from several emerging factors such as ethnicity. Data collection was obtained from online media reporting writers, interview websites, and research reports. This study found that identity cannot be separated in the Merauke district, where politics is considered to have its positives and negatives. The positive is to ensure that ethnic immigrants in the Merauke district respect indigenous peoples as owners of territory. The negative is that there is no right to become regent for the immigrant tribes in the Merauke district even though they have fulfilled the requirements as a leader. There are no rules regarding who has the right to lead in special autonomy in the Papua region. This case raises many things related to Papuans in Indonesia in particular.
\end{abstract}

Keywords: Political, identity, ethnicity, identity, local politics

\begin{abstract}
ABSTRAK
Pada Pemilihan Kepala daerah Kabupaten Merauke terjadi kontestasi antar suku untuk memenangkan kandidatnya. Pada kontestasi ini terjadi konflik antar suku yaitu suku asli papua dan suku pendatang Penelitian ini bertujuan membahas pertarungan politik kabupaten Merauke untuk mendapatkan dukungan politik melaui entnisitas. Penelitian ini menggunakan pendekatan kualitatif dengan penelitian analitis dari beberapa factor yang muncul seperti etnisitas. Pengumpulan data diperoleh penulis dari pemberitaan media online, website wawancara, dan laporan riset. Penelitian ini menemukan identitas tidak dapat terlepas di kabupaten Merauke dengan politik dianggap memiliki positif dan negatifnya. Positifnya adalah memastikan bahwa suku pendatang yang berada di kabupaten Merauke menghargai masyarakat adat sebagai pemilik atas wilayah. Negatifnya adalah tidak adanya hak untuk menjadi bupati bagi suku pendatang yang ada dikabupaten Merauke meskipun telah memenuhi syarat sebagai seorang pemimpin. Tidak adanya aturan terkait siapa yang berhak memimpin dalam otonomi khusus di wilayah papua. Kasus ini memunculkan banyak penafsiran terkait kekhususan orang-orang papua di Indonesia.
\end{abstract}

Kata Kunci: Politik, identitas, etnis, politik local

\section{INTRODUCTION}

The simultaneous Election of Regional Heads in Indonesia marks a progressive journey of local democracy. However, there are several questions: why are regional head elections so costly? What causes corruption in the congregation to occur after the Regional Head

Citation : Misran, Suardi, W., \& Qodir, Z. (2021). Ethnic Identity and Local Politics: Study on Regional Head Election in Merauke Regency 2020. Journal of Government and Civil Society, 5(2), 198-213. https:/ /doi.org/10.31000/jgcs.v5i2.4359 
Election? Why is identity politics a vote generator? This last question will be discussed in this article as a phenomenon of political identity in Indonesia.

Scientific analysis often overrules normative by using the term identity politics to describe any mobilization related to politics, ethnicity, culture, and identity (Bernstein 2005). Identity politics occupies a central position in most conflicts (Ben Moussa 2019). Although, according to Bliss (2013), identity politics, including (ethnicity and culture) should have been lost for a long time because, with all of them, development has nothing to do with social aspects. The social aspects in question, such as political status and influence, are visible and openly monopolized by one group, resulting in collective frustration and dissatisfaction (Jhon 2004).

Using their respective identities in contesting power in regional head elections, starting from culture, customs, villages, families, clans, and ethnic egos (Leonardo Snanfi et al. 2018). Identity itself is one of the special characteristics of a person and group (Rumbi 2019). Ethnic clashes occur due to the desire to get support from citizens to win the fight. The mobilization of residents occurs during the Regional Head Election.

The contestation for the election of regional heads and deputy regional heads for the Merauke Regency occurred in the 2020 Regional Head Election. The existence of special rights obtained by the Marine Tribe Indigenous Peoples led them to get the Birthright which the people of Merauke Regency indirectly recognized. This causes the immigrant community to be led by the indigenous Marind tribe.

Among fellow citizens of Merauke Regency, regent candidate pairs who are descendants of the local tribes (the Marind tribe) greatly influence their support. They support candidates from their clan but do not support people who are not from their tribes. Cultural differences in the community are considered as a barrier to choosing a candidate. This means the feasibility of being a regional leader and a cultural, social, symbolic, and economic capital approach is needed (Yelvington 2018).

Merauke Regency has a large population of 213,484 people, of whom 40,678 are indigenous Marind people (Wuniyu et al., 2019). However, it can be seen that the number of immigrants is 172,806 . Thus, the population of the Marind tribe is not much greater than that of the immigrants in Merauke Regency. However, this is not an obstacle for the Marind Indigenous Peoples to become leaders in Merauke Regency. As a region that has special rights from the State of Indonesia, it is an advantage. The Marin tribe can compete with non-indigenous tribes in Merauke.

The contestation for regional head and deputy regional head elections for Merauke Regency took place in the 2020 Regional Head Election. The special rights obtained by the Marind Indigenous Peoples led them to obtain birthright rights that the people of Merauke Regency indirectly recognize. This caused the immigrants to agree to be led by the indigenous Marind people. 
The Birthright is a right recognized by the local community and immigrants as a political policy for the local tribal community in Merauke Regency. One of the customary agreements in the Marind tribe is that the right to become a regional head must be the original descendant of the local tribal community. This only applies to candidates for the regional head. Meanwhile, the representatives can be from any ethnic group if they are considered capable and have the same vision and mission. The Birthright is also the highest ethic of the Merauke community to respect the Marind indigenous people, and it is still ongoing.

Seeing the phenomenon in 2020 in the contestation of regional head and deputy regional head elections in Merauke Regency, installing three candidates for regents and deputy regents, it appears that there is a contestation. The contestation took place between candidate pairs (01) Hendrikus Mahuze and H. Edi Santosa; (02) Heribertus S. Silubun and Bambang Sudji; (03) Romanus Mbaraka and H. Ridwan (Kusnadi 2020).

This article aims to find out the contestation related to the conditions for the election of the regional head of the Merauke district in obtaining political support involving ethnic identity. The novelty of this research has not previously examined the contestation of the election of regional heads and deputy regional heads of Merauke Regency by involving indigenous and immigrant tribes. This article will also look at Ethnic Identity in Getting Political Support in the Regional Head Election in Merauke Regency 2020. Where the population immigrants as an absolute majority when compared to indigenous peoples. There are two questions to be discussed in this article: How is the Birthright of Indigenous Peoples in Political Contest? What is the Power of Ethnic Identity in Winning Political Support?

\section{METHOD}

This research is a descriptive study using a qualitative approach. The research will provide an overview and understanding of the political conditions to support the regional head election in the Merauke district with the thickness of ethnic identity that occurs. This study uses primary data and secondary data. Primary data were taken from interviews with several informants, namely members of the Merauke Regency DPRD, Merauke Regency Party Members, Merauke Regency People, and Indigenous People in Merauke Regency. At the same time, secondary data are taken from journals, online media, websites. From the data source, then perform data reduction by summarizing and focusing on the results of interviews and documents obtained to provide a clearer picture; Display of document data obtained by the author in the form of text and narrative and; concluding the data obtained by the author to answer the formulation of the problem that the author has determined (Sugiyono 2010). 


\section{RESULTS And DISCUSSION Identity Politics}

The concept of identity politics is fundamentally different from political identity, but both are rooted in the same concept, namely identity. Identity itself comes from the Latin word "idem," which means "the same." In contrast, conceptually, identity refers to a shared identity, including recognition of a subject's existence, acceptance, and affiliation ( Putra, 2019).

Talking about identity groups that cannot be separated from the characters, Michael Foucault and Stuart Hall discuss identity theories. The essence of identity theory is to discuss how a specific identity can determine its destiny (self-determination), or in the language of Agness Heller (2007), a kind of political movement that focuses on differences as a major political category (Syuhudi, 2016).

According to Michael Foucault's view, identity cannot be separated from his conversation about the subject. The two are closely related and inseparable. If subjectivity is a condition as a person and how to be that person, then the conception to believe about ourselves is called identity. For Foucault, subjectivity is the discursive production of power, regulating what can be said about people in certain social and cultural conditions. In understanding identity, subjects or groups of subjects can fight for their identity. Furthermore, the subject can form and produce himself about who he is, which is called identity politics (Robet and Tobi, 2014, 156: 160).

Identity politics for Bagir is a name to describe a situation marked by the rise of identity groups in response to repression that marginalized them in the past. Identity turns into identity politics when it becomes the basis for group aspirations (Nugraha 2018). In this case, identity itself is one of a person and group (Rumbi 2019). This means not only about the feasibility of being a regional leader, but cultural, social, symbolic, and economic capital approaches are needed (Yelvington 2018)

The concept of identity is generally defined as an image that differentiates an individual/group from other individuals/groups built by individuals/groups. The group is modified continuously through interactions with other parties (Dauly, Kusmanto, and Kadir 2019). The practice of identity politics in Merauke Regency must be differentiated for the progress of the area because identity politics can be said, Good or positive in a democracy if it can provide solidarity values to build public awareness against injustice; Bad Does not actively promote positive public awareness, but does not threaten democracy by promoting the discourse of hostility and legalizing violence between identity groups; Ugly promotes values that prioritize the supremacy of one's group, emphasize negative views of other identity groups and legitimize violence (Ahnaf et al. 2015). 


\section{Political Contestation of People's}

Sovereignty in regional head elections directly faces sociological facts with the strengthening of ethnic currents in identity politics (Hemay and Munandar 2016). Ethnicity in regional head election contestation is used in three ways, (1) Mobility of ethnic symbols; (2) considerations of voters, and; (3) Selection and strategy of candidate leaders (local sons) (Aspinall 2011). Regional head elections took place after the decentralization policy was implemented in Indonesia. Historically, the implementation of decentralization is difficult to separate from the centralization of power at the center and the injustices that have plagued the regions and local tribes. During the authoritarian development regime, the New Order positioned Indonesia's cultural diversity as something that must be recognized. However, citizens' political rights should not be built on differences in culture or identity (Hemay and Munandar 2016).

Regional head elections are the main arena for contestation between socio-political forces, often based on tribal sentiment (Ahnaf et al., 2015). Identity politics in Indonesia began with the collapse of the New Order regime; political rights were then expressed as; the customary law community movement, the emergence of regional sons in politics, and demands for special autonomy for certain regions (Hemay and Munandar 2016). Political pragmatism and the marginalization of local community groups have encouraged strengthening identity politics; symbols of identity (ethnicity) are often the most prominent mobilization tools in regional head election contestation (Ahnaf et al., 2015).

In the Indonesian political system that adheres to democracy, the people are seen as the holder of the highest sovereignty, as seen from the director-general election. The people directly choose the person who will sit to lead the government by the current period. For this reason, democracy must produce results that will be felt by the people themselves, such as increased welfare, better state administration, and the security felt by the community.

Morrisan (2016) mentions an important aspect of the existence of a democracy, namely political participation. The underlying assumption of democracy (participation) is that the person who knows best about what is good for him is the person himself. Because decisions made and implemented by the government concern and influence the lives of citizens, the people have the right to participate in politics.

Political participation is an indicator in a country that adheres to a democratic system. This means that a country can be a democracy if the ruling government provides the widest possible opportunity for its citizens to participate in politics.

The participation of people conducting elections (Repi 2016) argues that it can be influenced by sociological factors on voter behavior, namely social class, economy, religion, ethnicity, gender, and aspects of the area of residence. Several main factors shape the effect of participation in Indonesia, one of which is the factor of ethnicity. Ethnic groups 
have a major role in shaping individual attitudes, perceptions, and orientations. This sense of ethnicity or regionalism can affect a person's support for a political party. Ethnicity can also influence loyalty to certain parties.

\section{Indigenous People and Immigrants}

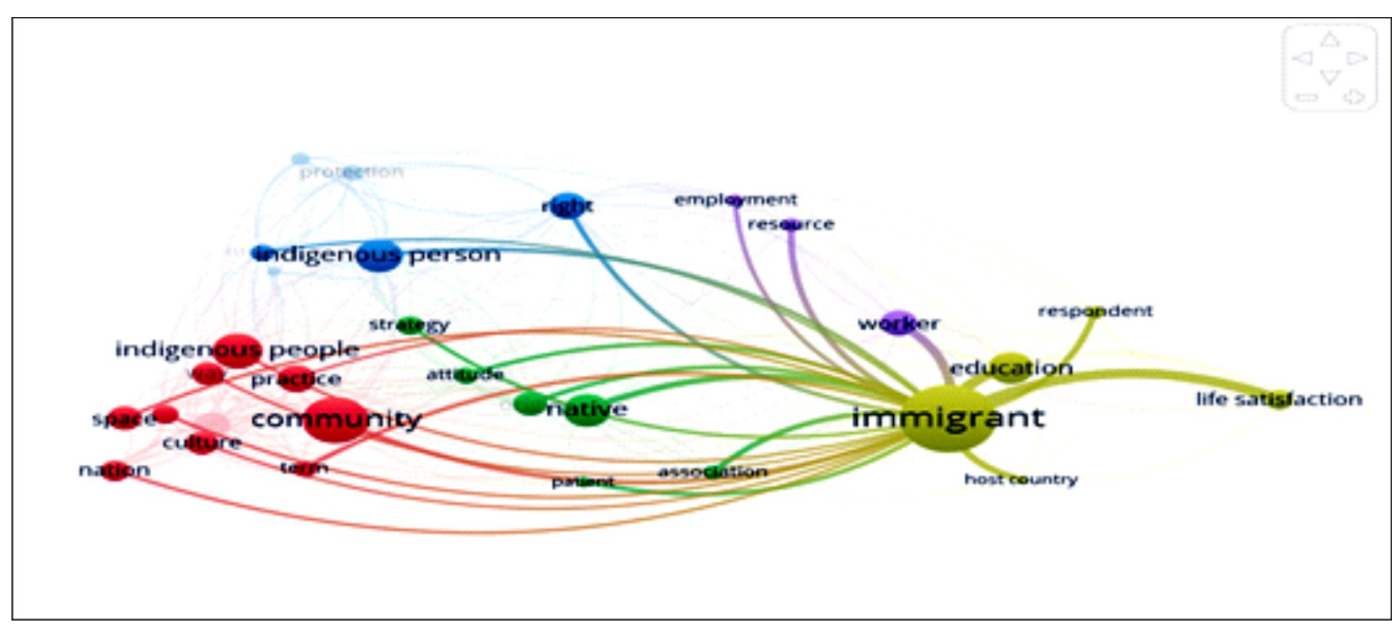

Figure 1. Visualization of Networks Related to Immigrant Communities

In the Ethnic Identity and Local Politics study in Merauke Regency, you can see the polarization and network using the Vosviwer aid app. There are two dominant and active identities, namely indigenous and immigrant. These two identities are active in contesting power in regional head elections, starting from culture, customs, village, family, clan, and ethnic egoism (Leonardo Snanfi et al., 2018). Identity itself is one of the special characteristics of a person and group (Rumbi 2019). Ethnic clashes occur due to the desire to get support from citizens to win the fight. The mobilization of residents occurs during the Regional Head Election.

\section{Identity Politics: Birth Rights of Indigenous Peoples in Political Contestation}

of Merauke Regency is not limited to the area of Merauke City but extends from the condo area to the City of Merauke. From interviews conducted with the people of Merauke district, the real name of the Merauke tribe is the Malind Tribe. Still, along with the addition of people in the Merauke district from various regions, the Malind Tribe is more often referred to as the Marine Tribe. The Regent election comes from Merauke (local people). It is necessary to know in advance that rights are jointly recognized between the indigenous people and the migrant communities; these rights are recognized as Malind Anim's Birthright. It is known that the Birthright is a right owned by the original Marind people who inhabited Merauke's land from the start. 
In an interview conducted on December 6, 2020, with members of the Merauke Regency PPP Party, this right provides several privileges, namely that the local community (the marine tribe) is the owner of the rights to the area so that the marine community has the right to have the opportunity to lead the area. The recognition of this Birthright is not without reason; some of these reasons are that the Birthright provides an opportunity for the native son of Marind as a regional leader in Merauke to appear as a solution provider for all problems Merauke. Not only that, it is believed that having a son of Marind as the regional head has more authority to deal with turmoil/conflict, for example, conflicts over customary rights or land claims.

A member of the PPP Party in Merauke Regency stated that recognizing this Birthright is important even though it is not recognized by law, but is to respect the voters for customary rights and maintain peace because various tribes in Papua are particularly important in Merauke. As well as paying attention to the culture of the people in Merauke district, especially Indigenous Papuans should be privileged as the basis for the birth of autonomous law. Also, maintain peace because the various tribes of Papua are especially in Merauke. As well as paying attention to the culture of the people in the Merauke district, especially Indigenous Papuans should be privileged as the basis for the birth of the special autonomy law.

Based on data from the Regional General Election Commission of Merauke Regency, only one of the three pairs of candidates for the regional head was born from a father and mother from the Marind tribe, namely, couple (03) Romanus Mbaraka. Meanwhile, the candidate pair (01), namely: Hendrikus Mahuze, was born to a mother who is a Chinese ethnic cross and a father from a native Marind tribe. Thus, the Mahuze clan that was obtained came from the clan of the father. Meanwhile, the pair of candidates (02), Heribertus S. Silubun is a traditional child adopted as the traditional child of the Kaize tribe (Lantipo 2019). Heribertus S. Silubun clan, namely, Silubun, identified that this clan is used by indigenous peoples from Maluku (Pattiiha 2019).

In several previous studies conducted by (Habibi 2018) on the analysis of identity politics in Indonesia, it is stated that people with differences need an analysis of the occurrence of identity politics in Indonesia. Unlike the case with research conducted by (Wuniyu et al. 2019) on the identity politics of Indonesian indigenous peoples (case study: Merauke Regency), it is concluded that the Marind tribe understands politics quite well that the Marind ethnic community has the right to accommodate their area. In a research conducted by (Bodjodah and Suhu 2019) on identity politics in the 2013 North Maluku Pilkada, KH. Abdul Gani Kasuba, LC and Ir. Muh. Natsir Thaib, because there are factors of ethnic strength and strong religious networks to build opinion and political marketing. 
From the interviews conducted, it can be concluded that during the reformation era, the Merauke district was never separated from a leader who was a descendant of the indigenous people of the Marind tribe. The existence of the Birthright begins with the conviction of being a native who wants a change related to his representation in the DPRD. This was done because the Marind people believed that their representation was lacking and was not by law number 21 of 2001 concerning special autonomy, which in Article 6 paragraph 4, namely that it should be enforced 11D 4 times the total number of DPRD members.

The political behavior of the Marind tribe is deliberately carried out due to several factors, namely the occurrence of inequalities in life such as increasingly limited employment opportunities, the basic rights of the Marind people who have been controlled; these conditions force the Marind community to make decisions that involve various actions. Actions related to these problems are also in line with the indirect socio-political environment in the form of situations. These namely conditions directly influence the community to undertake an activity to divide their rights. Furthermore, what further strengthens the Birthright to be recognized is the weakening representatives of marind people in the legislative seats and at least native Papuans who work as civil servants. First, the Legislative seats, it was noted that since the period 2004-2009, the number of ethnic marinated people was only 11 people, 2009-2014 as many as nine people, 20142019 as many as seven people. Then, there was a significant decrease for the 2019-2024 period, namely only 3 representatives of marind people in the DPR seats (Tobari 2019). Problems also arise in the Civil Servant sector, as seen through the Provincial Government Policy, which states that civil servant appointments in 2019 in all regions of Papua must meet a quota of 80 percent for native Papuans and 20 percent for non-native Papuans (Solo 2020). This has led to an unwritten policy that the Regent Candidate should be a native Merauke native, even though there is no rule explicit regarding which ethnic group has the right to become a leader in a particular area. It must recognize local policies as one of the efforts to prevent conflicts in the future. Thus the emergence of ethnic politics begins with a growing awareness that identifies them as a certain ethnic group or group that also needs to be prosperous (Habibi 2018).

This identity politics is carried out because the Marind tribe feels that their situation is increasingly marginalized from all aspects of life, which has changed their perspective with other ethnic groups, more specifically the immigrant community, where the Marind people feel that their lives are getting increasingly difficult in their places, jobs the more difficult it is for them to find both the private and government sectors, development is more dominant in transmigration areas than local areas (Wuniyu et al. 2019). On this occasion, it is in line with the opinion expressed by Agnes Heller that identity politics is a concept and a political movement whose focus is on differences as the main political category (Nasrudin 2018). 


\section{The Power of Ethnic Identity in Getting Political Support}

Talking about identity groups that cannot be separated from the characters, Michael Foucault and Stuart Hall discuss many theories of identity. The essence of identity theory is to discuss how an individual identity can determine its destiny (self-determination), or in Agness Heller's language (2007), a kind of political movement that focuses its attention on differences as a significant political category (Muhammad Irfan Syhudi 2016).

Identity, according to Michael Foucault, cannot be separated from his discussion of the subject. The two are closely related and cannot be separated. If subjectivity is a condition of being a person and how to be, then this conception of believing about ourselves is called identity. For Foucault, subjectivity is the discursive production of power, which governs what can be said about people in specific social and cultural conditions. In the understanding of identity, the subject or group of subjects can fight for their identity. Furthermore, the subject can form and produce themselves about who he is, called identity politics (Robet and Tobi, 2014, 156:160).

Talking about identity groups that cannot be separated from the characters, Michael Foucault and Stuart Hall discuss many theories of identity. The essence of identity theory is to discuss how a specific identity can determine its destiny (self-determination), or in Agness Heller's language (2007), a kind of political movement that focuses its attention on differences as a significant political category (Muhammad Irfan Syhudi 2016).

Identity, according to Michael Foucault, cannot be separated from his discussion of the subject. The two are closely related and cannot be separated. If subjectivity is a condition of being a person and how to be, then this conception of believing about ourselves is called identity. For Foucault, subjectivity is the discursive production of power, which governs what can be said about people in specific social and cultural conditions. In the understanding of identity, the subject or group of subjects can fight for their identity. Furthermore, the subject can form and produce themself about who he is, which is called identity politics (Robet and Tobi, 2014, 156:160).

Identity politics is the political use of human beings who prioritize the interests of a group because of the similarity of identity that includes race, ethnicity, gender, or a particular religion. Politics is often used in the past. For example, Adolf Hitler convinced the German people that the source of the economic crisis and the defeat of the world war was due to the influence of the Jews. With sweet promises to raise Germany, Hitler and his party won the elections in 1932. The solution he offered was to eliminate the Jews, and that promise was sold and bought by most of the German people. This resulted in the tragedy that occurred in Germany when the Nazis came to power. Six million Jews became victims of the atrocities of identity politics, and it became one of the worst genocidal events recorded in world history. In Indonesia, identity politics is more related to ethnicity, religion, ideology, and local interests generally represented by political elites with their 
respective articulations. -each. The regional expansion movement or the change of government power includes making identity politics one of its political tools. Issues of justice and regional development have become very central in their political discourse so that they are more influenced by the ambitions of local elites to emerge as leaders.

Data released by the provincial government of Papua in 2018 stated that Merauke Regency has an area of 46, $791.63 \mathrm{~km}^{2}$ with 20 districts, 179 villages, and 11 villages. Merauke Regency is inhabited by 213,484 people and native Papuans (ethnic marind) of 40,678 people (Wuniyu et al. 2019). There are 30 ethnic groups living side by side in Merauke district. It started with the presence of the Javanese tribe in 1893 . There are 59 residential units with an average family of 500 people per unit area. In 2018, the number of Javanese people in Merauke district was 45,000, and of course, this will increase until 2020. That is why the Javanese tribe has the largest number of people in the transmigration area. This is in line with the definition of identity politics from (Habibi 2018), which states that identity politics is another name for biopolitics and difference politics. In this case, it cannot be denied that the identity politics that occurs in Merauke Regency is due to the many differences between the people in the area.

The information above was confirmed by members of the PPP party who stated that in 2020 the regional head elections in Merauke district, all deputy regional head positions were filled by people with Javanese ethnic backgrounds based on the consideration of the number of Javanese population in Merauke district. The following is the data regarding the ethnic groups of the three pairs of candidates for regional heads and their deputies.

Table 1. List of Ethnic Groups of Candidates for Regional Leaders of Merauke Regency 2020-2025

\begin{tabular}{|ccc|}
$\begin{array}{c}\text { ORDER } \\
\text { NUMBEROF }\end{array}$ & \multicolumn{2}{c|}{ IDENTIFICATIONCANDIDATES BASED ON ETHNIC } \\
\hline 01 & PROSPECTIVE REGENTS & $\begin{array}{c}\text { PROSPECTIVE } \\
\text { REPRESENTATIVES }\end{array}$ \\
\hline & Hendrikus Mahuze: & Edi santosa: \\
& Father of China; Marind & Javanese \\
\hline 02 & Heribertus Silubun: & Bambang; \\
& $\begin{array}{c}\text { The Kei (Maluku) tribe was adopted as the } \\
\text { traditional child of Marind Kaize }\end{array}$ & Javanese \\
\hline 03 & Romanus Mbaraka; & $\begin{array}{c}\text { Muhammad } \\
\text { Riduwan: }\end{array}$ \\
& Marind original from Kimam & Javanese \\
\hline
\end{tabular}

Source: Results of Interviews with Informants and Researchers 
In the context of the view of political parties as bearers of Regent candidates, it is believed that every candidate who is nominated must have quality and maintain peace in Merauke Regency. Regarding the election of a deputy regent from the Javanese tribe, it is believed that most immigrant tribes are Javanese in Merauke, so that the rational basis for choosing a deputy regent is Javanese.

In the 2020 regional head elections, it is known that the candidate pairs of regents are one of the original descendants of the Marind tribe, namely Romanus Mbaraka and Hendrikus Mahuze, who also have a marind clan. Still, he got the clan from his mother. In the Merauke district, it is customary to adopt a customary child. If adopted as a traditional child of the Marind tribe, of course, you have the opportunity to become a regional head in Merauke district. From the information obtained from members of the Merauke Regency DPRD (Paskalis Letsoin), it is stated that the strength of candidate pair number 03 is quite strong because of the three pairs of regent candidates there is only one who is of pure marind descent without other ethnic mixtures. Although it does not close the opportunity for other couples to process and be elected as regional heads in Merauke district.

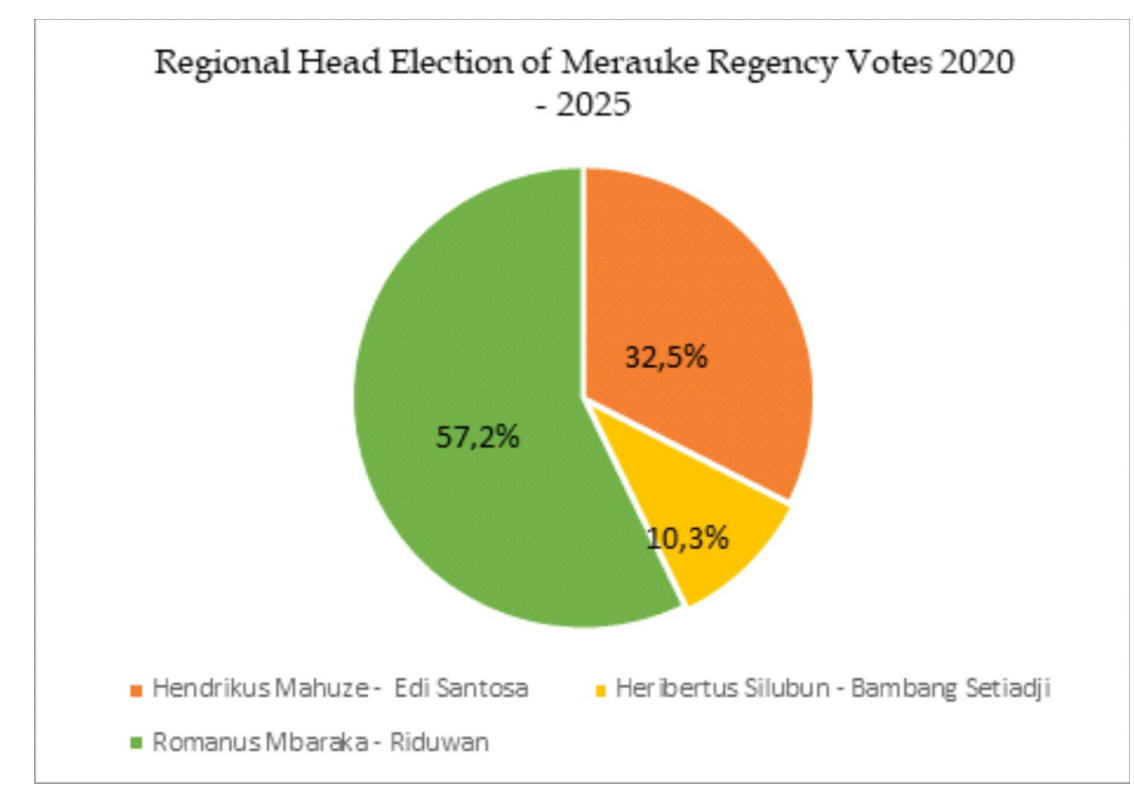

Figure 2. Votes for The Election of Merauke Regency 2020-2015 Source: General Election Commission of Merauke Regency

The data above shows the vote acquisition for the Merauke district general election in the 2020-2025 district. Romanus Mbaraka - Riduwan won the votes announced by the general election commission of Merauke district, Romanus Mbaraka - Riduwan, with a total vote of $57.2 \%$ who are believed to be indigenous tribal peoples of the original Marind 
tribe. This proves that the indigenous people of the Marind tribe are struggling for their Birthright, which has been attached to all areas of Papua, especially Merauke district. Following this was followed by Hendrikus Mahuze - Edi Santosa with 32.5\% of the votes. 02 votes quite a lot. This is seen from the family background of Hendrikus Mahuze who was born to his parents; The mother of the Marind Tribe and the father of the Chinese tribe. However, the candidate pair number 03 was quite far too far, namely $10.3 \%$. From the interviews conducted by researchers, it can be concluded that the background of the candidate for district head 02, Heribertus Silubun, is very influential even though he has the right to lead because he is a customary child who was officially adopted by the Marind Kaize tribe. However, it does not rule out that there is only one among the many groups in the Marind tribe.

Seeing the phenomenon in Merauke district, ethnic identity is very influential to become a regional head. Leadership in Merauke district since the reform era, each period has been filled by the district head who is a native ethnic group. With various considerations ranging from political power, the existence of a pair of candidates to their eligibility, it is quite influential. It becomes an added value in the eyes of the community. This is inseparable from the birthright rights obtained by the indigenous people of the Marind tribe, which are recognized by immigrants from various tribes in Merauke district. Likewise, according to Lukmantoro, the definition of identity politics is political to prioritize the interests of members of a group because they have the same identity or characteristics, whether based on race, ethnicity, gender, or religion (Nasrudin 2018).

\section{CONCLUSION}

Merauke is one of the districts that has become the center of attention in Papua Province. As a regency that is located in the easternmost part of Indonesia, of course, there are many things that must be considered for the progress of the region. One of them is in the political and government sectors. The fact that Merauke district is separated from its identity politics, which is increasingly considered normal, has its positives and negatives. The positive thing is to ensure that the migrant tribes living in the Merauke district respect the indigenous people as owners of the territory. The negative thing is that there is no right to become a regent for the immigrant tribes in Merauke Regency even though they have fulfilled the requirements as a leader. The absence of regulations regarding who has the right to lead in special autonomy in the Papua region, especially Merauke district, certainly raises many interpretations of the specificity of the Papuan people in Indonesia. 


\section{REFERENCES}

Ahnaf, Mohammad Iqbal;, Samsul; Maarif, Budi Asyhari; Afwan, and Muhammad. Afdillah. 2015. Politik Lokal Dan Konflik Keagamaan: Pilkada Dan Struktur Kesempatan Politik Dalam Konflik Keagamaan Di Sampang, Bekasi Dan Kupang. Yogyakarta: Center for Religion \& Cross-Cultural Studies.

Aspinall, Edward. 2011. "Democratization and Ethnic Politics in Indonesia: Nine These." Ournal of Eas Asian Studies 11.

Bernstein, Mary. 2005. "Identity Politics." Annual Review of Sociology 31:47-74. doi: 10.1146/annurev.soc.29.010202.100054.

Bliss, Catherine. 2013. “The Marketization of Identity Politics." Sociology 47(5):1011-25. doi: $10.1177 / 0038038513495604$.

Bodjodah, Aswir, and Bakri Suhu. 2019. "Politik Identitas Di Pilkada Maluku Utara." Kawasan Volume XI.

Dauly, Sayed Muhammad, Heri Kusmanto, and Abdul Kadir. 2019. "Politik Identitas Pada Pemilihan Gubernur Sumatera Utara Tahun 2018." Jurnal Administrasi Publik/: Public Administration Journal 9(1):51. doi: 10.31289/jap.v9i1.2230.

Dharma Kelana Putra. 2019. “Jurnal Antropologi: Isu-Isu Sosial Budaya |." 02:236-44.

Habibi, Muhammad. 2018. "Analisis Politik Identitas Di Indonesia." INA-Rxiv Papers (March). doi: 10.31227/osf.io/pey72.

Hemay, Idris, and Aris Munandar. 2016. "Politik Identitas Dan Pencitraan Kandidat Gubernur Terhadap Perilaku Pemilih." Jurnal Politik Universitas Nasional 12(1):173748.

Jhon, Pieris. 2004. Tragedi Maluku (Sebuah Krisis Peradaban). Jakarta: Yayasan Obor Indonesia.

Kusnadi. 2020. “KPU Merauke Tetapkan Tiga Paslon Bupati Dan Wakil Bupati Pemilu 2020." InfoPublik.

Lantipo, Yuliana. 2019. "Diangkat Jadi Anak Adat, Heribertus Silubun Di Kecam.” Jubi. Co.Id.

Leonardo Snanfi, Ferinandus, Muhadjir Darwin, - Setiadi, and Hakimul Ikhwan. 2018. “Politik Identitas Etnik Asli Papua Berkontestasi Dalam Pemilihan Kepala Daerah Di Kota Sorong." Sosiohumaniora 20(2):122-31. doi: 10.24198/ sosiohumaniora.v20i2.15089.

Moleong, Lexy J. 2007. Metodologi Penelitian Kualitatif. Penerbit PT Remaja Rosdakarya Offset, Bandung.

Morrisan. 2016. “Tingkat Partisipasi Politik Dan Sosial Generasi Muda." Visi Komunikasi 15(01):96-113.

Ben Moussa, Mohamed. 2019. "Rap It up, Share It up: Identity Politics of Youth 'Social' Movement in Moroccan Online Rap Music." New Media and Society 21(5):1043-64. doi: 10.1177/1461444818821356. 
Muhammad Irfan Syuhudi. 2016. "Muhammad Irfan Syuhudi, Geliat Politik Identitas Di Kota Manado." Hamroni, Jurnal Multikultural \& Multireligius 15(2):56-66.

Nasrudin, Juhana. 2018. “Politik Identitas Dan Representasi Politik (Studi Kasus: Pilkada DKI Periode 2018-2022)." Hanifiya: Jurnal Studi Agama-Agama Volume 1 N.

Nugraha, Firman. 2018. "Gerakan Ekonomi Keagamaan Dan Politik Identitas Muslim Pedesaan ( Studi Di BMT Dana Akhirat Kecamatan Arjasari Kabupaten Bandung )." Jurnal Bimas Islam 2(4):693-722.

Pattiiha, Thaha. 2019. "FAM(Marga), Nama Matarumah Di Kepulauan Maluku." Academia.Edu.

Repi, sondakh gideon. 2016. "Partisipasi Politik Masyarakat Dalam Pemilihan Gubernur Dan Wakil Gubernur Sulawesi Utara 2015 (Studi Di Desa Koha Selatan Kecamatan Mandolang Kabupaten Minahasa)1." Jurnal Politico 5(1).

Rumbi, Frans Paillin. 2019. “Politik Identitas Etnis Toraja Sebagai Masalah Teologis: Khusus Di Kabupaten Kolaka, Sulawesi Selatan." Teologi Dan Pendidikan Agama Kristen Vol. 5, No:125-38.

Solo, Martinus. 2020. “Dua Tahun Hasil Tes CPNS Papua Barat Belum Keluar.” Media Indonesia.

Sugiyono. 2010. Metode Penelitian Pendidikan Pendekatan Kuantitatif, Kualitatif, Dan RED. Bandung: Alfabeta.

Sugiyono. 2016. Metode Penelitian Kuantitatif Kualitataif Dan Kombinasi (Mixed Methods). Bandung: Alfabeta.

Tobari. 2019. "Kursi Khusus Adat DPRD Kabupaten-Kota Diperjuangkan Ke Presiden." InfoPublik.

Wuniyu, Fransiskus;, Hamka; Naping, Achmad; Zulfikar, Sukri;, and Sosiawati. 2019. “Politik Identitas Masyarakat Adat Di Indonesia: Studi Kasus Di Kabupaten Merauke." x(x):1-15. doi: 10.31227/osf.io/ryk86.

Yelvington, Kevin A. 2018. “'A Conference That Didn't': African Diaspora Studies and an Episode in Anthropology's Identity Politics of Representation." Critique of Anthropology 38(4):407-32. doi: 10.1177/0308275X18806574.

Ahnaf, Mohammad Iqbal;, Samsul; Maarif, Budi Asyhari; Afwan, and Muhammad. Afdillah. 2015. Politik Lokal Dan Konflik Keagamaan: Pilkada Dan Struktur Kesempatan Politik Dalam Konflik Keagamaan Di Sampang, Bekasi Dan Kupang. Yogyakarta: Center for Religion \& Cross-Cultural Studies.

Aspinall, Edward. 2011. “Democratization and Ethnic Politics in Indonesia: Nine These." Ournal of Eas Asian Studies 11.

Bernstein, Mary. 2005. "Identity Politics." Annual Review of Sociology 31:47-74. doi: 10.1146/annurev.soc.29.010202.100054. 
Bliss, Catherine. 2013. “The Marketization of Identity Politics." Sociology 47(5):1011-25. doi: $10.1177 / 0038038513495604$.

Bodjodah, Aswir, and Bakri Suhu. 2019. "Politik Identitas Di Pilkada Maluku Utara." Kawasan Volume XI.

Dauly, Sayed Muhammad, Heri Kusmanto, and Abdul Kadir. 2019. "Politik Identitas Pada Pemilihan Gubernur Sumatera Utara Tahun 2018." Jurnal Administrasi Publik/ : Public Administration Journal 9(1):51. doi: 10.31289/jap.v9i1.2230.

Dharma Kelana Putra. 2019. “Jurnal Antropologi: Isu-Isu Sosial Budaya |." 02:236-44.

Habibi, Muhammad. 2018. "Analisis Politik Identitas Di Indonesia." INA-Rxiv Papers (March). doi: 10.31227/osf.io/pey72.

Hemay, Idris, and Aris Munandar. 2016. "Politik Identitas Dan Pencitraan Kandidat Gubernur Terhadap Perilaku Pemilih." Jurnal Politik Universitas Nasional 12(1):173748.

Jhon, Pieris. 2004. Tragedi Maluku (Sebuah Krisis Peradaban). Jakarta: Yayasan Obor Indonesia.

Kusnadi. 2020. “KPU Merauke Tetapkan Tiga Paslon Bupati Dan Wakil Bupati Pemilu 2020." InfoPublik.

Lantipo, Yuliana. 2019. “Diangkat Jadi Anak Adat, Heribertus Silubun Di Kecam.” Jubi. Co.Id.

Leonardo Snanfi, Ferinandus, Muhadjir Darwin, - Setiadi, and Hakimul Ikhwan. 2018. "Politik Identitas Etnik Asli Papua Berkontestasi Dalam Pemilihan Kepala Daerah Di Kota Sorong." Sosiohumaniora 20(2):122-31. doi: 10.24198/ sosiohumaniora.v20i2.15089.

Moleong, Lexy J. 2007. Metodologi Penelitian Kualitatif. Penerbit PT Remaja Rosdakarya Offset, Bandung.

Morrisan. 2016. “Tingkat Partisipasi Politik Dan Sosial Generasi Muda." Visi Komunikasi 15(01):96-113.

Ben Moussa, Mohamed. 2019. "Rap It up, Share It up: Identity Politics of Youth 'Social' Movement in Moroccan Online Rap Music." New Media and Society 21(5):1043-64. doi: 10.1177/1461444818821356.

Muhammad Irfan Syuhudi. 2016. "Muhammad Irfan Syuhudi, Geliat Politik Identitas Di Kota Manado." Hamroni, Jurnal Multikultural \& Multireligius 15(2):56-66.

Nasrudin, Juhana. 2018. "Politik Identitas Dan Representasi Politik (Studi Kasus: Pilkada DKI Periode 2018-2022)." Hanifiya: Jurnal Studi Agama-Agama Volume 1 N.

Nugraha, Firman. 2018. "Gerakan Ekonomi Keagamaan Dan Politik Identitas Muslim Pedesaan ( Studi Di BMT Dana Akhirat Kecamatan Arjasari Kabupaten Bandung )." Jurnal Bimas Islam 2(4):693-722.

Pattiiha, Thaha. 2019. “FAM(Marga), Nama Matarumah Di Kepulauan Maluku.” Academia.Edu. 
Repi, sondakh gideon. 2016. "Partisipasi Politik Masyarakat Dalam Pemilihan Gubernur Dan Wakil Gubernur Sulawesi Utara 2015 (Studi Di Desa Koha Selatan Kecamatan Mandolang Kabupaten Minahasa)1." Jurnal Politico 5(1).

Rumbi, Frans Paillin. 2019. "Politik Identitas Etnis Toraja Sebagai Masalah Teologis: Khusus Di Kabupaten Kolaka, Sulawesi Selatan." Teologi Dan Pendidikan Agama Kristen Vol. 5, No:125-38.

Solo, Martinus. 2020. “Dua Tahun Hasil Tes CPNS Papua Barat Belum Keluar." Media Indonesia.

Sugiyono. 2010. Metode Penelitian Pendidikan Pendekatan Kuantitatif, Kualitatif, Dan RED. Bandung: Alfabeta.

Sugiyono. 2016. Metode Penelitian Kuantitatif Kualitataif Dan Kombinasi (Mixed Methods). Bandung: Alfabeta.

Tobari. 2019. "Kursi Khusus Adat DPRD Kabupaten-Kota Diperjuangkan Ke Presiden." InfoPublik.

Wuniyu, Fransiskus;, Hamka; Naping, Achmad; Zulfikar, Sukri;, and Sosiawati. 2019. "Politik Identitas Masyarakat Adat Di Indonesia: Studi Kasus Di Kabupaten Merauke." x(x):1-15. doi: 10.31227/osf.io/ryk86.

Yelvington, Kevin A. 2018. “'A Conference That Didn't': African Diaspora Studies and an Episode in Anthropology's Identity Politics of Representation." Critique of Anthropology 38(4):407-32. doi: 10.1177/0308275X18806574. 